\title{
Description of the difference in plaque index between normal and autistic children age 6-12 years
}

\section{Arinda M. Nadya, Sasmita S. Inne', Nonong Yetty ${ }^{1}$}

Student at Faculty of Dentistry, Padjadjaran University, 1Department of Pediatric Dentistry, Faculty of Dentistry, Padjadjaran University, West Java, Indonesia

Address for the Correspondence:

Dr. Inne S. Sasmita, Department of Pediatric Dentistry, Faculty of Dentistry, Padjadjaran University, West Java, Indonesia.

E-mail: innesuhernasasmita@ yahoo.com

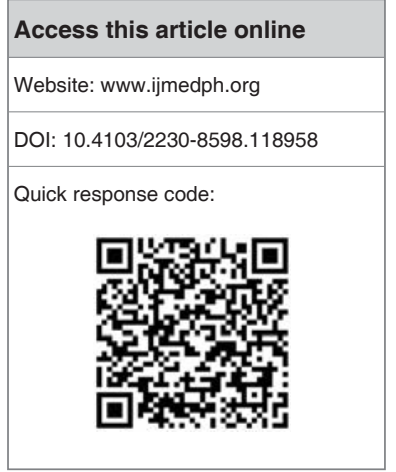

Background: Oral hygiene status can be seen from the plaque index contained in the mouth. Children aged 6-12 years are school age, they can be taught about oral health care independently. The research objective was to obtain data about description of the differences in plaque index between normal and autistic children aged 6-12 years in Yayasan Autisme Ourdream, Lembaga Pendidikan Autisme Prananda, and SDN Banjarsari in the Bandung city. Materials and Methods: This study was a descriptive analytic. The population was all the students at SDN Banjarsari and autistic children aged 6-12 years in both the foundation. Samplings were collected by simple random sampling, the number of samples obtained normal and autistic children each were 21 persons. Clinical examinations for plaque index using Patient Hygiene Performance (PHP) index of Podshadley and Halley. The data were analyzed with independent $t$-test. Results: The results showed an average of plaque index normal and autistic children aged 6-12 years was 2.06 with a standard deviation of 0.573 and 3.23 with a standard deviation of 0.473 . Conclusion: The conclusions showed that there were significant differences in plaque index between normal and autistic children, these values are equally moderate category by Patient Hygiene Performance (PHP) index of Podshadley and Halley.

Key words: 6-12 years, normal and autistic children, patient hygiene perfirmance index, plaque index

\section{INTRODUCTION}

Plaque is a soft deposit consisting of extracts of bacteria that breed in a matrix formed and firmly attached to the tooth surface or other hard surfaces did the oral cavity including the natural restoration of removable or fixed if oral hygiene is neglected. ${ }^{[1]}$ One way to get rid of plaque is to brush your teeth. Ability to brush teeth properly is an important factor for the maintenance of oral health. ${ }^{[2]}$

Plaque can't be eliminated but can be removed by rinsing, brushing your teeth, but every individual especially children is not as easy to remove plaque adults, because children are still in the stage of growth and development. In normal children of age 6-12 years, fine and gross motor skills are still in their infancy. Children at this age are generally capable to maintain oral health in more detail, that causes a sense of responsibility for own hygiene. The maintenance of oral health should be done at an early age. The role of schools is necessary in the process of creating brushing habits in children. Elementary school age is the ideal time to train a child's motor skills, including brushing teeth. ${ }^{[3]}$

A child will experience a period of growth and development in the span of life. The process through which the growth and development of each child's certainly is not the same and have the hallmark of each individual. Problems faced also vary from one child to another. Problems can be interference with the development of physical and or mental. One such disorder is autism. ${ }^{[4]}$

Autism is a complex developmental disorder and severe, symptoms began to appear at age less than 3 years. Developmental disorders include communication, interaction and behavior. ${ }^{[5]}$ People with autism exhibit poor oral health condition because the condition is not like a normal child, whereas behavior that is difficult to accept instruction and rejection of people and a new environment cause dental care is rather difficult to do. The average height of periodontal disease in children with autism is 
associated with mouth hygiene status were affected by the disruption of interaction, behavior and apathetic attitude that made him unable to care for their own teeth at home and depend on their parents to clean. But for parents whose children suffer from autism are aware of the importance of oral health will always support efforts in the maintenance of oral hygiene so that children with autism are maintained teeth and mouth hygiene. ${ }^{[6,7]}$

Our dream Autisma Foundation and the Institute of Education Autism tempay Prananda is chosen by the researchers because it has been qualified as having students aged 6-12 years old and are willing to be a place to do research. While SDN Banjarsari randomly selected from the entire school that meets the requirements for doing research.

\section{Aim and objective on the study}

The research objective was to obtain data on the picture of the plaque index difference between the normal and autistic children aged 6-12 years.

\section{MATERIALS AND METHODS}

This type of research is descriptive analytical and sampling for researchers using simple random sampling technique.

\section{Subjects and methods}

This type of research is a descriptive analytic aimed to see differences in plaque index normal and autistic children.

The population in the study were the students of SDN Banjarsari and children at the Institute of Education Autisma "Prananda" and Our Dream Foundation in Bandung.

Selection of SD for normal children taken by raffle of several elementary schools in the city of Bandung with the following criteria: ${ }^{[8]}$

1. Elementary school students who have an age range 6-12 years

2. SD to the average student has a social strata comparable population of children with autism in the Autism Foundation

3. SD tests of psychomotor, cognitive and affective students

4. Willing and able to work together to do research in elementary school.

\section{Statistical analysis}

The sample size was determined based on the level of $95 \%$ and $80 \%$ power test, using a sample size formula for two average test are:

$$
n=\frac{2 s^{2}(Z \alpha \times Z \beta)^{2}}{d^{2}}
$$

$n=$ sample size

$\mathrm{s}=$ standard deviation

$\mathrm{Z} \alpha, \mathrm{Z} \beta=$ Retrieved from standard normal distribution table

$d=$ Big difference in mean plaque index of autistic children and normal children by previous studies.
Based on the above, formula obtained for the second sample size of each population group of 21 people per group.

\section{Cross tabulation analysis}

Analysis of cross-tabulations present data in a tabulated form that includes rows and columns. Characteristic of cross tabulation is the two or more variables that have a relationship with the descriptive data presented in the form of quantitative.

\section{Independent testing using two independent samples $t$-test}

Hypothesis test

H0: $B=0$ There were no differences in autistic children with plaque index of dental plaque index normal child.

$\mathrm{H} 1: \mathrm{B} \neq 0$ There are differences in plaque index autistic child with dental plaque index child Normal.

Error level $(\alpha)$ is well tolerated in this study at $5 \%(0.05)$. Reject $\mathrm{H}_{0}$ if $\mathrm{t}_{\text {count }}>\mathrm{t}_{\text {table }(\alpha, \mathrm{n}-2)}$ or a $p<\alpha$, received in other cases. According to Table 1, it can be seen $\mathrm{t}_{\text {count }}=|7221|<2021=\mathrm{T}_{\text {table }(0.05,40)}$, and the $P$ value of 0 which is smaller than the value of his error tolerance is 0.05 , so it was decided that $\mathrm{H}_{0}$ is rejected.

\section{DISCUSSION}

PHP Index (Patient Hygiene Performance Index) of Podshadley and Haley, is the first index that was developed as a basic purpose of estimating a person's view of oral hygiene in removing debris after brushing instructions. PHP Index also the method is simpler and more sensitive in the inspection plaque index and can be used both in providing dental health education and in research. ${ }^{[9]}$

Table 2 shows a picture of normal children and children with autism based on gender, namely 27 male (64.29\%) and 15 female (35.71\%) consisted of 10 male and 11 female and 17 normal young male and 4 female children with autism. This is consistent, with theories regarding the incidence of autism is more common in male than female is $4-5: 1 .^{[10,11]}$

\begin{tabular}{lcccl}
\multicolumn{4}{l}{ Table 1: Independent $\boldsymbol{t}$-test } \\
\hline Variables & $\boldsymbol{t}$ & $\mathbf{d f}$ & $\begin{array}{c}\boldsymbol{P} \text { value } \\
\text { decision }\end{array}$ & Conclusion \\
\hline $\begin{array}{l}\text { Plaque index } \\
\text { autistic children }\end{array}$ & 7.221 & 40 & $\begin{array}{c}0.000 \mathrm{H}_{0} \\
\text { Ignore }\end{array}$ & $\begin{array}{l}\text { There is a difference } \\
\text { in plaque index } \\
\text { Plaque index } \\
\text { normal children }\end{array}$ \\
\hline
\end{tabular}

\begin{tabular}{lccccc}
\multicolumn{2}{l}{ Table 2: Preview sample by sex } & & \\
\hline Sex & \multicolumn{2}{l}{ Normal children } & & \multicolumn{2}{c}{ Child autism } \\
\cline { 2 - 3 } \cline { 5 - 6 } & $\mathbf{f}$ & $\%$ & & $\mathbf{f}$ & $\%$ \\
\hline Man & 10 & 47,62 & & 17 & 80,95 \\
Female & 11 & 52,38 & & 4 & 19,05 \\
Total & 21 & 100.00 & & 21 & 100.00 \\
\hline
\end{tabular}




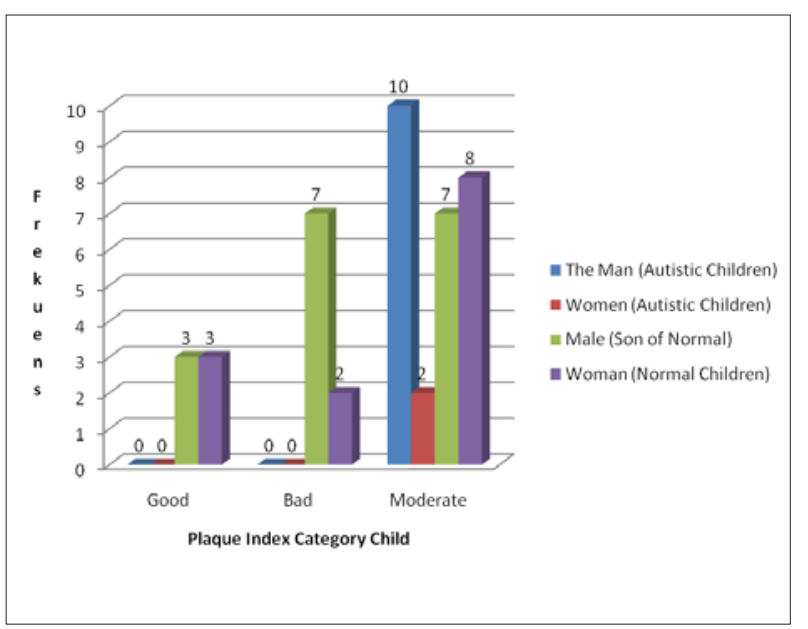

Figure 1: Plaque index category child

According to Bonnie Auyeung study in 2009, suggested that brain dysfunction threshold males tend to be lower than females. Exposures to male hormone testosterone in high levels in the fetus in the womb, have a higher risk for autism are born with a tendency properties. Girls have higher estrogen levels than male, hormone itself has neuroprotective effects on development that can protect the brain. However, the specific factors causing autism incidence is higher in male than female are still not known with certainty until today. ${ }^{[12]}$

Figure 1 is a graph of the cross-tabulation table to determine the combination of plaque index category of children with sex of the child. In 21 children with autism, it appears that most of the children are those who have moderate plaque index, of 12 children $(57.14 \%)$ male as many as 10 children (47.62\%), and the rest are female, as many as 2 children $(9.52 \%)$. The remaining 9 children $(42.86 \%)$ are those with plaque index in the poor category, amongst them $7(33,33 \%)$ are male and $2(9,52 \%)$ are female.

In 21 normal children, it appears that most of the children are basically with moderate plaque index, which reached as many as 15 children $(71.43 \%)$ who were young. Among 15 young children, there were $8(38.10 \%)$ female and the rest are $7(33,33 \%)$ male. The remaining 6 children $(14.29 \%)$ are the others who had plaque index in good category, $3(7.14 \%)$ male, and the rest are $3(7.14 \%)$ female. It can be seen that the trend of young girls in a plaque index teeth are better than boys.

Table 1 shows the independent $t$-test and concluded that the level of $95 \%$, there are significant differences in children with autism plaque index higher than normal children. Most children with autism have problems in the development of fine motor skills so he moved a motion of rigid and rugged, this leads to children with autism have difficulty in holding objects, including tooth brush. ${ }^{[13]}$

In research conducted by Thamrin (2002), the level of oral hygiene in children with autism in Agca (Agil Calep) Center Bandung showed poor results. ${ }^{[14]}$ While from research conducted Aditya (2005), the level of oral hygiene normal children in elementary Sinarjaya 1 and 3 showed Garut poor results. ${ }^{[15]}$

Brushing teeth for normal children is a common and simple task, but for children with autism, brushing teeth is a difficult task. Children with autism do not like or reject anything foreign objects into the mouth. ${ }^{[16]}$

\section{CONCLUSION}

The conclusions showed that there were significant differences in plaque index between normal and autistic children with an autistic child plaque index higher than normal children.

\section{REFERENCES}

1. Carranza AF, Newman MG. Clinical periodontologi. $9^{\text {th }}$ ed. Philadelphia: W.B Saunders; 2002. p. 96-105,182-8.

2. Wendari S. The role of oral hygiene in the prevention of caries and periodontal disease. Surabaya: Univ. Airlangga: Majalah Kedokteran Gigi; 2001. p. 37-40.

3. Pinkham JR, Casamassimo PS, Fields HW Jr, Dennis J. Mc Tigue, Nowak A. Pediatric dentistry infancy through adolescence. Missouri: Elseiver Saunders; 2005. p. 517,650,654-5.

4. Papalia. Human Developmental. $8^{\text {th }}$ ed. New York: McGraw Hill; 2001.p. 24.

5. Partakusuma FB. Prevention behaviors of children with autism in dentistry. Dentika Dent J 2003;8:37-8.

6. Noerdin S. Dental care in children with autism. Dentika Dent $\mathrm{J}$ 2001;6:36-41.

7. McDonald RE, Bell RA, Dean JA, Avery DR. Dentistry for the child and adolescent. $8^{\text {th }}$ ed. St. Louis: Mosby Company; 2004.p. 584.

8. Cochran WG. Tekhnik penarikan sampel. Jakarta: Universitas Indonesia 1991;135

9. Podshadley AG, Haley JV. A method for evaluating oral hygiene performance. Public health Rep 1968;83:259-64.

10. Sadock BJ, Sadock VA. Pervasive development disorders. Dalam H, Kaplan I. Sadock BJ. editors, sypnosis of psychitary behavioral sciences clinical psychiatry. $9^{\text {th }}$ ed. Philadelphia: Lippicontt Williams and Wilkins; 2003.p. 1208-15.

11. Behrman RE, Kliegman RM, Jenson HB. Neson textbook of pediatric dentistry. 17 $7^{\text {th }}$ ed. Philadelphia: W.B Saunders Company; 2004.p. 93.

12. Auyeung B, Baron-Cohen S, Ashwin E, Knickmeyer R, Taylor K, Hackett G. Fetal testosterone and autistic traits. Br J Psychol; 2009;100:1-22.

13. Veskarisyanti GA. 12 The most effective autism therapies and saving for Autism, hyperactivity, and mental retardation. Yogyakarta: Pustaka Anggrek; 2008.p. 42.

14. Thamrin FH. Level of oral hygiene in children with autism in Agil Calep (AGCA) Center Bandung Skripsi. Bandung: FKG Unpad; 2002.p. 34.

15. Aditya. of oral hygiene and gum on Student SDN Sinarjaya 1 and 3 Garut. Skripsi. Bandung: FKG Unpad; 2005.p. 45.

16. Powers MD. Children with autism: A parent's guide. $2^{\text {nd }}$ ed. Bethesda MD: Woodbine House; 2000.p. 28.

How to cite this article: Nadya AM, Inne SS, Yetty N. Description of the difference in plaque index between normal and autistic children age 6-12 years. Int J Med Public Health 2013;3:197-9.

Source of Support: Nil, Conflict of Interest: None declared. 